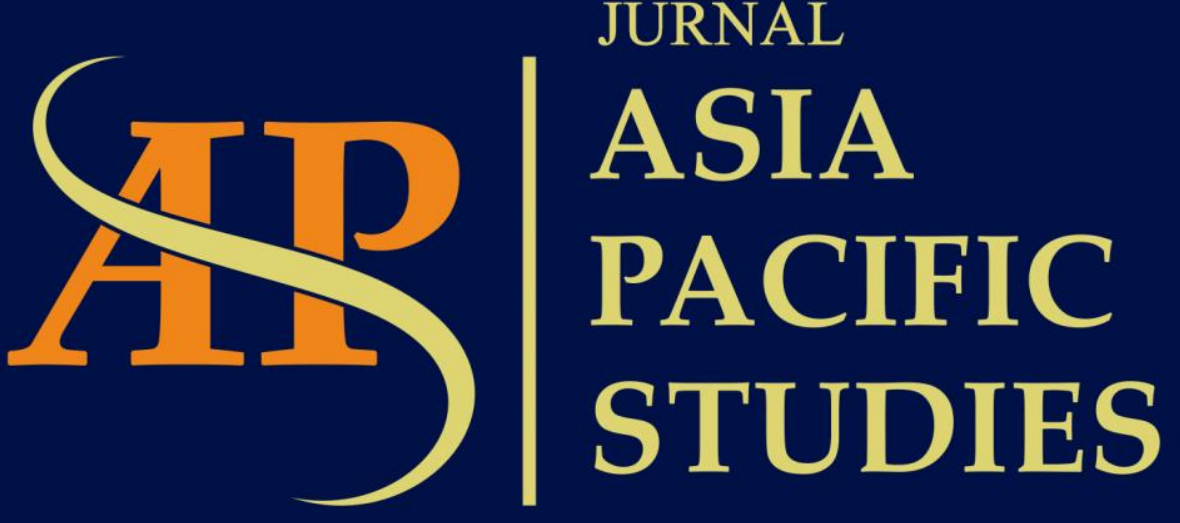

Journal of International Relations Study Program Faculty of Social and Political Sciences

Universitas Kristen Indonesia

Volume 2 | Number 1 | January - June 2018 


\title{
PENGARUH PERBEDAAN BUDAYA DAN POLITIK TERHADAP DINAMIKA PERSAINGAN KEKUATAN EKONOMI AUSTRALIA DAN CHINA DI KAWASAN ASIA PASIFIK
}

\author{
${ }^{1}$ Hardi Alunaza SD, ${ }^{2}$ Sunarti, ${ }^{3}$ Ireng Maulana \\ ${ }^{123}$ Prodi Ilmu Hubungan Internasional \\ Fakultas Ilmu Sosial dan Ilmu Politik, Universitas Tanjungpura \\ Jl. Profesor Dokter H. Hadari Nawawi, Bansir Laut, Pontianak Tenggara, \\ Kota Pontianak, Kalimantan Barat 78115 \\ 'hardialunaza@gmail.com
2snarti888@yahoo.com
maulanaireng81@gmail.com
}

\begin{abstract}
Australia and China are two countries in Asia Pacific, which their economic growth is quite high in the World. The capitalist economic atmosphere is very influential on the economic cycle in the Asia Pacific region. The differences in cultural and social values between these two countries give different features in the economic power of each country, namely Western for the Australia and Eastern for the China. The difference is compounded by the strength of two different ideologies behind both Liberal for Australia and Communist for China. This paper is attempted to answer how the comparison of power between cultural and social different Australia and China in the Asia Pacific region. The authors are using rivalry based on interdependence theory. Furthermore, this paper is using descriptive method with qualitative approach. The data collection technique is based on literature study consisting of books, journals, and including data from the reliable websites in order to support the explanation of this paper. The result of this paper shows that Australia's economic growth is sustained by financial and insurance services, which is a result of the high public awareness of developed countries. While China's economic growth is sustained by infrastructure investment, which is part of the industrialization process in developing countries. In order to move the Asia-Pacific region in term of economic, China and Australia build cooperate with Asia-Pacific countries by entering the membership of Asia-Pacific Economic Community (APEC) and Regional Comprehensive Economic Partnership (RCEP).
\end{abstract}

Keywords: Ideology, Culture and Politics, Economic Power.

\begin{abstract}
Abstrak
Australia dan China adalah dua negara di Asia Pasifik dengan pertumbuhan ekonominya cukup tinggi di dunia, dengan atmosfer ekonomi kapitalis yang sangat berpengaruh terhadap siklus perekonomian di kawasan Asia Pasifik. Perbedaan nilai-nilai budaya dan sosial antara dua negara ini memberikan corak yang berbeda dalam kekuatan ekonomi masing-masing negara, yaitu Australia yang barat dan China yang timur. Perbedaan tersebut ditambah dengan kekuatan dua ideologi yang diadopsinya, yaitu Australia yang liberal dan China yang komunis. Tulisan ini ingin menjawab bagaimana perbandingan kekuatan antara Australia dan China yang berbeda budaya dan sosial dalam bidang ekonomi di Asia Pasifik dengan menggunakan teori rivalitas dalam interdependensi. Tulisan ini menggunakan metode deskriptif dengan pendekatan kualitatif. Data yang digunakan dalam penelitian ini adalah data yang terdiri dari buku, jurnal, dan data dari situs website yang mendukung penjelasan artikel ini. Hasil penelitian menunjukkan bahwa pertumbuhan ekonomi Australia ditopang oleh layanan keuangan dan asuransi, yang merupakan imbas dari kesadaran masyarakat yang cukup tinggi di negara maju. Sedangkan pertumbuhan ekonomi China ditopang oleh investasi infrastruktur, yang merupakan bagian dari proses industrialisasi di negara berkembang. Dalam rangka menggerakkan kawasan Asia Pasifik dalam bidang ekonomi, China dan Australia melakukan kerja sama dengan negara-negara Asia Pasifik dengan masuk dalam keangotaan Asia-Pacific Economic Community (APEC) dan Regional Comprehensive Economic Partnership (RCEP).
\end{abstract}

Kata Kunci: Ideologi, Budaya dan Politik, Kekuatan Ekonomi. 


\section{Pendahuluan}

\subsection{Latar Belakang}

Wilayah Asia Pasifik adalah wilayah yang berbatasan dengan Samudera Hindia. dan sebagian besar merupakan negara-negara Asia Tenggara, Asia Timur, Australia, Selandia Baru, bahkan India (Connors, 2004). Wilayah Asia Pasifik termasuk wilayah yang sangat strategis, terutama untuk kepentingan ekonomi karena menghubungkan kawasan Asia Tenggara, Asia Timur, Australia, benua Amerika bahkan Asia Selatan.

Perkembangan perekonomian Australia dan China di kawasan Asia Pasifik menjadi salah satu contoh bagi negara tetangganya. Australia dan China memberikan model terbaik mereka dalam mengelola perekonomian dalam negeri sekaligus kerja sama dengan negara lain dalam rangka meningkatkan ekonomi melalui berbagai kebijakan ekonomi. Sejarah perkembangan ekonomi Australia dan China adalah salah satu hal yang paling penting untuk dibahas berkaitan dengan pembangunan berkelanjutan dari perekonomian kedua negara tersebut.

Kapitalisme di Australia berawal saat kolonisasi Inggris pada tahun 1890-an dengan menekankan produksi komoditas primer kolonial seperti pertanian dan peternakan untuk mendorong ekspor Inggris ke negara lain di dunia. Komoditas yang diekspor Inggris ini akan membuka jalur hubungan kerja sama perdagangan Inggris dengan negara-negara di dunia terutama negara-negara Asia (McMichael, 1984).

Pemerintah kolonial pada masa itu membangun infrastruktur di Australia untuk meningkatkan "investasi" sebagai salah satu cara untuk memperluas dan menegaskan imperialismenya. Setelah terbentuknya Negara Persemakmuran Australia, perekonomian Australia tidak mengalami perubahan dengan masih berada dalam kendali dari kekuatan imperial Inggris. Pada masa modern ini, perekonomian Australia yang merupakan turunan kapitalisme Inggris memiliki penopang dari berbagai sektor yaitu industri, agribisnis, investasi, bisnis, dan ekspor.

Sejarah perkembangan ekonomi China dapat ditelusuri melalui dinasti Han (206 SM$220 \mathrm{M}$ ), dinasti Han melakukan perdagangan dengan wilayah barat laut melalui jalur sutera. Selama dinasti Tang (618-901M) perdagangan berkembang pesat hingga kerajaan Romawi (Chow, 2005).

China mulai menerapkan ekonomi kapitalis pada masa Presiden Deng Xiaoping dengan kebijakan ekonomi Gaige Kaifang (reformasi dan membuka diri) pada tahun 1979. Dengan kebijakan ekonomi tersebut, China memulai bekerja sama dengan pihak luar, membuka lahan investasi bagi investor-investor asing, dengan menjadikan kota-kota di Pantai Timur sebagai pintu utama datangnya investasi asing (Jati, 2013). Dalam bukunya yang membahas mengenai kapitalisme, Johan Norberg menjelaskan mengenai perubahan Tiongkok setelah mereformasi perekonomiannya.

"Tiongkok memberikan hak kepada warga negaranya terutama petani untuk mengolah tanahnya sendiri yang tentu saja dapat mendorong produktivitas petani dan meningkatkan kesejahteraan dan kemakmuran mereka. Dalam kurun 20 tahun setelah reformasi, pertumbuhan ekonomi tahunan Tiongkok konon hampir sepuluh persen, dan produk domestik brutonya (PDB) telah meningkat empat kali lipat. 20 tahun perekonomian bangsa ini telah melambung pesat; mula-mula menyamai perekonomian Jerman, kemudian melampaui gabungan perekonomian Jerman, Prancis, Italia dan negaranegara Nordik sekaligus. Liberalisasi tahun 1979 telah memungkinkan 800 
juta petani Tiongkok menggandakan pendapatan mereka dalam selang enam tahun saja. (Norberg, 2011)."

Pertumbuhan perekonomian Tiongkok dalam 20 tahun sejak 1979 memang sangat pesat hingga dapat menyamai perekonomian sebagian negara di Eropa seperti Jerman, Prancis, Italia dan negara-negara Nordik sekaligus. Perubahan siklus perekonomian yang terjadi merupakan bentuk keberhasilan China dalam menerapkan sistem kapitalisme setelah era Mao, dengan pemberian hak kepada para petani, pembukaan pasar, dan peningkatan kerja sama dengan negara lain.

\subsection{Rumusan Masalah}

Melalui pertimbangan semakin tingginya persaingan Australia dan China di Kawasan Asia Pasifik, maka rumusan masalah dalam tulisan ini adalah bagaimana perbandingan kekuatan antara Australia dan China yang berbeda budaya dan politik dalam bidang ekonomi di Asia Pasifik? Tulisan ini akan menjelaskan persaingan keduanya yang dijelaskan dengan menjabarkan peran apa saja yang dilakukan oleh kedua Negara melalui forum multilateral di kawasan Asia Pasifik.

\subsection{Tujuan Penulisan}

Tujuan penulisan tulisan ini adalah membahas tentang perbandingan kekuatan ekonomi antara Australia dan China di kawasan Asia Pasifik dan pengaruhnya terhadap politik di kawasan. Penulis membagi artikel ini menjadi tiga bagian. Pertama yaitu perbandingan ekonomi antara Australia dan China: industri dan investasi. Kedua, kerja sama Australia dan China dengan negara tetangga di kawasan Asia Pasifik. Ketiga, pengaruh kerja sama ekonomi antara Australia dan China terhadap politik di kawasan Asia Pasifik.

\section{Kajian Pustaka dan Kerangka Pemikiran}

\subsection{Rivalitas dalam Interdependensi}

Menurut pandangan Realisme, terdapat beberapa asumsi utama yang mendasari hubungan antara satu negara dengan negara lain. Salah satu asumsi tersebut adalah negara, sebagai aktor utama dan terpenting dalam dunia yang anarki, senantiasa mengedepankan kepentingan nasional (Viotti \& Kauppi, 2010). Realisme memandang negara sebagai aktor yang rasional dan tunggal yang memperhitungkan cost and benefit dari setiap tindakannya untuk menjamin keamanan nasional. Fokus dari paradigma ini adalah struggle of power atau real politik dalam menjalin hubungan dengan Negara lain secara bilateral maupun multilateral (Perwita \& Yani, 2005: 126). Mengingat paradigma Realisme memandang masalah ekonomi dan keamanan nasional sebagai perhatian utama negara maka masalah militer dan ekonomi yang berhubungan dengan dimensi politik merupakan masalah yang paling penting bagi Negara. Dalam pandangan tersebut, hubungan antara Australia dan Cina selalu didasari oleh kepentingan nasional masing-masing, khususnya perluasan pengaruh dalam rangka memperoleh power di kawasan Asia Pasifik.

Dalam bidang ekonomi, Realisme berpendapat bahwa proses menuju dan kemajuan ekonomi dapat menyebabkan terjadinya konflik antar-negara. Menurut Morgenthau, Realisme melihat politik sebagai sebuah area yang berkaitan dengan keinginan untuk memperoleh kekuasaan (struggle for power), termasuk di dalamnya kekuasaan ekonomi. Dengan demikian, ekonomi tidak dapat dilepaskan dari power dan interest yang dalam pemenuhannya dapat 
menggunakan segala cara termasuk dengan kompetisi yang dapat berujung pada konflik (Morgenthau, 1993: 50). Konsep Realisme tentang relative gains juga mendasari terbentuknya sebuah kerja sama dalam institusi regional karena hubungan aliansi dan kerja sama ekonomi yang muncul juga akan didasari oleh perhitungan relative gains dan security dilemma yang dialami oleh negara. Oleh karena itu, persaingan antara Australia dan China dalam institusi regional di Kawasan Asia Pasifik dapat dilihat sebagai sebuah instrumen untuk mempertahankan power di kawasan tersebut.

Sementara itu, menurut Chalmers Johnson, institusi regional yang menjamin keamanan di Asia Pasifik dapat terbentuk apabila didasari oleh interdependensi antara aktoraktor besar yang ada di kawasan tersebut, khususnya Negara-negara maju seperti Australia dan China. Oleh karena itu, teori tentang persaingan dalam interdependensi sangat tepat untuk melihat persaingan antara Australia dan China dalam konteks kepemimpinan di dalam integrasi kawasan Asia Pasifik. Secara umum, interdependensi dianggap sebagai sarana untuk mewujudkan perdamaian dan keamanan bagi wilayah yang bermasalah, seperti kawasan Asia Pasifik dengan meningkatkan hubungan dagang dan ekonomi yang akan mencegah terjadinya konflik. Akan tetapi, di dalam interdependensi itu sendiri selalu muncul persaingan antaraktor besar yang didasari oleh berbagai alasan sehingga dapat menyebabkan konflik (Keohane, 1989: 247).

Ketika dua negara yang mempunyai sejarah konflik dan persaingan berada dalam satu situasi dimana keduanya terikat oleh interdependensi yang tinggi, hal ini menciptakan sensitivitas yang dapat membahayakan hubungan tersebut. Keohane dan Nye dalam (Veronica, 2014: 21) menyatakan bahwa peningkatan interdependensi dapat memperburuk ketegangan antara kedua negara yang sebelumnya tidak terbiasa saling berhubungan dekat. Jika pemimpin politik dimotivasi oleh ambisi nasional, keinginan untuk meraih kepentingan tertentu seperti kepentingan ekonomi yang ekspansionis dalam menjalankan hubungan antar-negara, persaingan (rivalry) dalam interdependensi menjadi hal yang sangat mungkin terjadi. Interdependensi dipandang secara berbeda oleh komunitas ekonomi dan komunitas keamanan dalam sebuah sistem politik karena adanya perbedaan sifat kedua komunitas tersebut yang menyebabkan perbedaan kebutuhan untuk keberlangsungan komunitas tersebut.

Manfaat utama interdependensi adalah tergerusnya oleh sifat utama negara untuk mengedepankan kepentingan nasionalnya, seperti yang dinyatakan oleh kaum Realis. Dalam sebuah institusi regional, interdependensi ekonomi antara satu negara dengan negara saingannya dapat dianggap sebagai sebuah kerentanan (vulnerability). Ini terjadi apabila hasil dari interdependensi yang membawa pada kemajuan ekonomi negara saingan dapat digunakan untuk meningkatkan kapabilitas militer dan sistem persenjataan yang canggih. Pada akhirnya, persaingan yang muncul di dalam proses interdependensi ini akan membawa pada konflik yang tak terhindarkan karena setiap negara mengedepankan kepentingan nasional dan menjadikannya sebagai instrumen untuk mengimplementasikan.

\section{Objek dan Metodologi Penelitian}

Pada dasarnya sebuah penelitian adalah kegiatan yang dilakukan untuk mencari jawaban terhadap pertanyaan yang ingin diketahui penulis. Penelitian tentang perbedaan budaya dan politik terhadap dinamika persaingan kekuatan ekonomi Australia dan China di Asia Pasifik termasuk penelitian deskriptif dengan pendekatan kualitatif. Penulis berusaha untuk mendeskripsikan keadaan objek serta permasalahan yang ada. Oleh karena itu, metode deskriptif diharapkan dapat mencapai tujuan penelitian, yaitu menggambarkan secara jelas fakta dan karakteristik objek yang diteliti secara tepat.

Teknik analisa data yang digunakan mengacu kepada Miles dan Huberman, dimana kegiatan analisis terdiri dari tiga alur kegiatan yang terjadi secara bersamaan, yaitu reduksi 
data, penyajian data, dan penarikan kesimpulan atau verifikasi (Sugiyono, 2011: 246). Dalam menganalisa penelitian ini penulis menggunakan pola induksi dengan tiga tahapan yakni: (1) Mengumpulkan data-data tentang fenomena yang diteliti, (2). Pengolahan, pada tahapan ini peneliti mengolah data untuk di pilah-pilah, mana yang cocok dan sesuai dengan kategori yang dibutuhkan oleh masing-masing sub-bab penelitian, (3). Analisa, tahapan terakhir ini menjadikan data yang mentah dan sudah diolah tadi, untuk kemudian di analisa dan di interpretasikan oleh peneliti sehingga mempengaruhi proses pembentukan hasil akhir dari riset.

Untuk mempermudah penulis maka analisa data juga akan dilakukan bersamaan pada saat data terkumpul. Penulis menggunakan metode pengumpulan data yang bersifat studi pustaka untuk lebih mengakuratkan penelitian dari sisi keilmuan. Metode ini dilaksanakan dengan topik permasalahan yang diangkat melalui penelitian terhadap buku, tulisan, artikel, dan hasil penelitian mengenai objek kajian yang diteliti. Selain itu, penulis juga mencari data yang relevan dengan penelitian ini dari media elektronik dengan sumber yang dapat dipercaya (reliable).

\section{Hasil dan Pembahasan}

\subsection{Ekonomi Australia dan China (Industri dan Investasi)}

Bertahannya siklus ekonomi yang dinamis dalam suatu negara sangat berkaitan erat dengan industri yang sedang berkembang dan berjalan di negaranya. Investasi tidak bisa dipisahkan dari industri, melalui investasi, sebagian besar industri dalam suatu negara dapat berjalan, baik investasi yang dilakukan oleh pemerintah maupun swasta. Investasi ini dapat berupa investasi terhadap industri layanan masyarakat, manufaktur, konstruksi, dan lainnya.

Pentingnya investasi dan industri di era globalisasi, ekonomi juga dipergunakan untuk meningkatkan interaksi antar negara yang secara tidak langsung menuntut efisiensi dan efektivitas dalam pemenuhan kebutuhan masyarakat. Untuk memenuhi kebutuhan hidup masyarakat yang semakin meningkat dan beragam dalam suatu negara. Pemenuhan kebutuhan ini dilakukan dengan berbagai cara dimulai dengan meningkatkan jumlah produksi yang berbiaya murah, inovasi teknologi, dan meningkatkan kerja sama dengan negara lain dalam berbagai bidang.

Perekonomian Australia yang ditopang melalui investasi dalam berbagai industri, seperti industri jasa, konstruksi, manufaktur dan pertambangan yang memiliki total investasi sebesar \$123,6 milyar pada tahun 2015-2016. Investasi di bidang pertambangan sebesar \$52,4 milyar pada tahun 2015-2016. Dibandingkan dengan tahun 2014-2015, investasi di bidang pertambangan sebesar \$74,8 milyar - turun sebesar 29,9 persen. Pada bulan Maret 2016, investasi di bidang pertambangan mengalami penurunan, berada di bawah investasi jasa dan konstruksi untuk pertama kalinya sejak Desember 2011. 
Grafik 1. Grafik investasi industri jasa dan konstruksi, pertambangan, dan manufaktur di Australia (2006-2016).

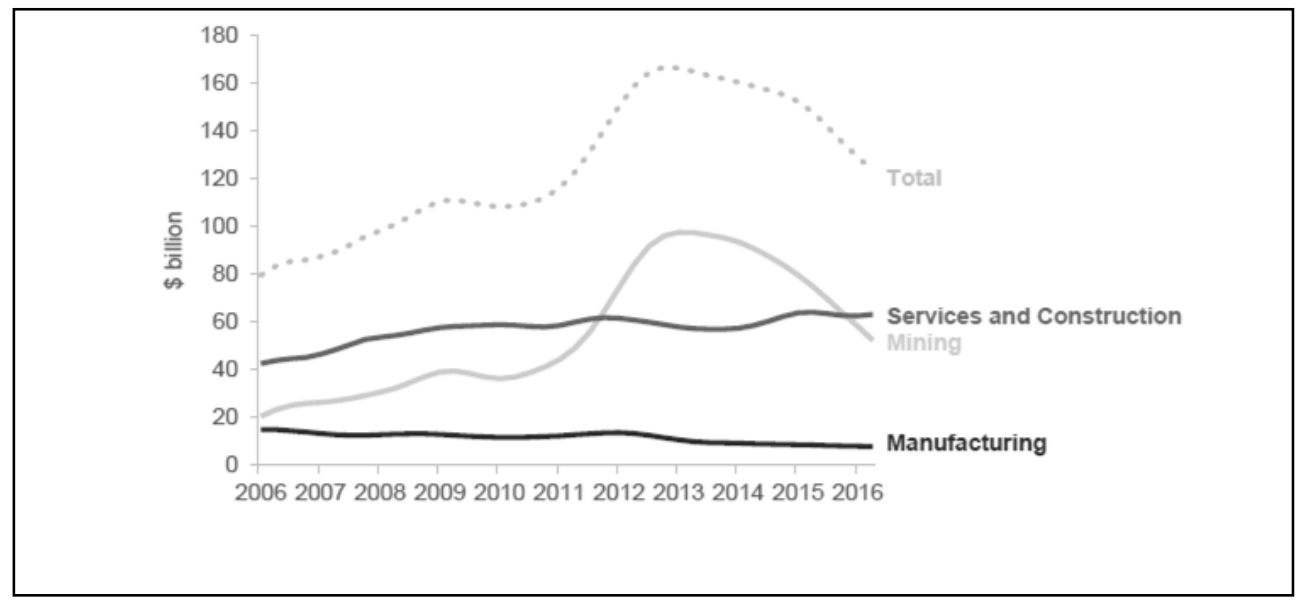

Sumber: Australian Industry Report 2016

Pada tahun 2016, industri manufaktur Australia mengalami beberapa perubahan, terutama setelah produksi terakhir Ford pada bulan Oktober di Australia. Perubahan ini juga terjadi karena adanya program pembangunan infrastruktur baru yaitu Future Submarine Program, yaitu pembangunan armada baru kapal selam Australia di Adelaide.

Kemajuan teknologi industri yang ada di Australia merupakan contoh kemajuan teknologi barat. Kemajuan teknologi akan lebih cepat berpindah dari satu negara ke negara lain yang kurang lebih memiliki kehidupan budaya dan sosial yang sama. Dalam kasus Australia, kemajuan teknologi merupakan warisan dari Revolusi Industri Inggris. Berbagai kemajuan tersebut teknologi pada akhirnya membantu memberikan kemajuan dalam bidang ekonomi seperti pemanfaatan robot dalam industri.

Tabel 1. Penghasilan dan pekerjaan dalam bidang industri (2015-2016).

\begin{tabular}{|lrrrr|}
\hline \multicolumn{2}{|l|}{ Table 2.1: Output and employment by industry, 2015-16 } & & \\
Industry & $\begin{array}{r}\text { Output } \\
\text { (\$ billion) }\end{array}$ & $\begin{array}{r}\text { Share of GDP } \\
\text { (per cent) }\end{array}$ & $\begin{array}{r}\text { Employment } \\
\text { (million) }\end{array}$ & $\begin{array}{r}\text { Share of all industry } \\
\text { (per cent) }\end{array}$ \\
\hline Services & $1,015.1$ & 61.1 & 9.4 & 79.2 \\
Mining & 114.9 & 6.9 & 0.2 & 1.9 \\
Construction & 134.2 & 8.1 & 1.1 & 8.8 \\
Manufacturing & 99.4 & 6.0 & 0.9 & 7.4 \\
Agriculture & 36.7 & 2.2 & 0.3 & 2.7 \\
All industries & 1,400 & 84.3 & 11.9 & 100 \\
& & & & \\
\hline
\end{tabular}

Sumber: Australian Industry Report 2016

Berbeda dengan Australia, perekonomian China ditopang oleh investasi infrastruktur yang merupakan bagian dari rencana pengembangan regional dengan menghubungkan Beijing-Hebei-Tianjin. Selain itu, investasi yang saat ini sedang berkembang pesat adalah investasi perumahan yang merupakan hasil dari pengembangan investasi real estate di China, investasi meningkat secara tajam pada tahun 2016. 


\section{Grafik 2. Peningkatan investasi perumahan di China}

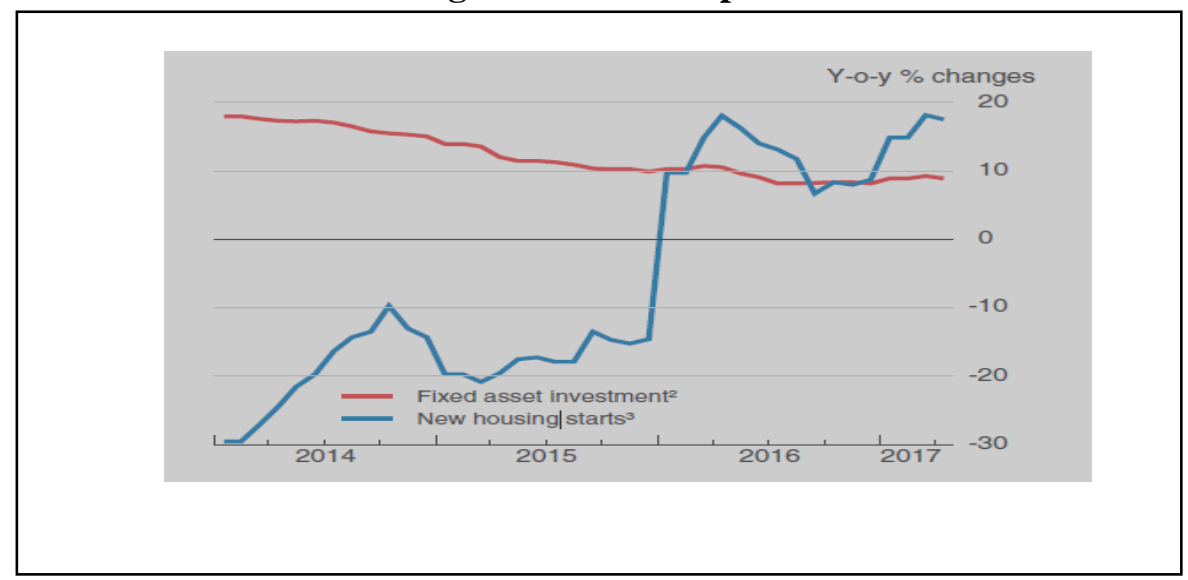

Sumber: OECD Economic Outlook 2017

Pusat perhatian ekonomi China saat ini adalah investasi ke berbagai negara di dunia melalui Foreign Direct Investment (FDI), melalui investornya yang melakukan investasi ke berbagai negara, investor China merupakan salah satu pelaku ekonomi yang sangat penting bagi perekonomian China. Salah satu kawasan yang menjadi sasaran dari para investor China adalah kawasan Eropa. Benua ini dapat dikatakan menjadi salah satu pasar bagi China. Pada tahun 2015, melalui FDI, China dapat mencapai \$130-140 milyar, naik dari tahun 2014 yang mencapai \$123 milyar (Haneman \& Houtari, 2016). Investor China lebih banyak berinvestasi di Eropa dalam bidang teknologi, merek, layanan masyarakat, dan aset terkait konsumen. Investasi yang paling banyak dilakukan adalah investasi teknologi informasi, telekomunikasi, dan layanan keuangan.

Populasi yang besar di China saat ini menyediakan bonus demografi yaitu jumlah pekerja produktif yang melimpah. Industri China dalam kaitannya dengan bonus demografi ini, memanfaatkan sumber daya manusia yang melimpah tersebut untuk dipekerjakan di pabrik-pabrik dengan gaji yang kecil. Bonus demografi China merupakan salah satu alasan pendorong meningkatnya perekonomian China saat ini (Chomsky, 2016).

Sumber kekuatan ekonomi Australia dan China melalui berbagai penelusuran data di atas ternyata memiliki perbedaan yang cukup besar, di antaranya disebabkan oleh perbedaan geografis, budaya, dan sosial antara kedua negara tersebut. Pertambangan yang berkembang pesat di Australia disebabkan karena sebagian besar wilayahnya terdiri dari gurun pasir, sehingga bisnis dan industri pertambangan menjadi sesuatu yang sangat diminati di Australia. Sedangkan China, yang baru terlepas dari sistem ekonomi tertutup pada tahun 1978 mengalihkan perhatiannya ke investasi infrastruktur untuk meningkatkan perdagangan dan proses industrialisasi di negaranya. Selain itu, China juga membangun kerja sama dengan Negara lain untuk meningkatkan perekonomiannya yaitu melalui FDI.

Perbandingan kekuatan ekonomi antara Australia dan China dapat dilihat dari investasi dalam suatu bidang unggulan yang dipadukan dengan sumber daya alam dan sumber daya manusia. Australia bergantung pada bidang layanan kesehatan seperti asuransi yang disebabkan oleh tingginya kesadaran penduduk Australia akan kesehatan dan keselamatan diri. Sementara China memiliki keunggulan dalam bidang investasi infrastruktur dan perumahan, yang kedua-duanya sangat dipengaruhi oleh tingginya angka penduduk China.

Melihat dari PDB kedua negara pada tahun 2016, China mengalami pertumbuhan PDB sebesar 6,6\% dan Australia sebesar 2,8\%. Perbedaan pertumbuhan PDB yang cukup besar antara kedua negara tidak dapat menegaskan bahwa China lebih kuat dalam bidang ekonomi dibanding Australia. Ini disebabkan oleh beberapa faktor, seperti jumlah penduduk, kemiskinan, dan pengangguran. 


\subsection{Kerja Sama Australia dan China dengan Negara di Kawasan Asia Pasifik}

Kerja sama yang dilakukan oleh Australia dan China dengan negara-negara kawasan Asia Pasifik terdapat dalam berbagai bidang seperti di bidang politik, keamanan, ekonomi, maupun pendidikan. Kerja sama yang banyak dan strategis dilakukan oleh Australia dan China adalah kerja sama dengan negara di Asia Tenggara. Pengaruh kerja sama ekonomi yang dilakukan oleh Australia dan China dengan negara lain dapat dilihat melalui perbedaan nilainilai yang dibawa oleh keduanya. Namun, memiliki kekuatan ekonomi yang dapat dikatakan hampir sama. Status Australia sebagai negara maju, dapat disaingi oleh China melalui pertumbuhan ekonomi yang sangat cepat.

Kedua negara ini dalam menyampaikan kepentingan ekonominya melalui organisasi ekonomi regional maupun internasional. Salah satunya organisasi atau bentuk integrasi kawasan Asia Pasifik adalah Asia-Pacific Economic Community (APEC). Australia memprakarsai organisasi APEC pada tahun 1989 dan China masuk menjadi anggota pada tahun 1991. Menurut (Aris Prasetyo, 2011) APEC adalah:

"Forum kerja sama ekonomi di Asia Pasifik yang dibentuk pada tahun 1989 dan membahas isu ekonomi khususnya pembentukan liberalisasi perdagangan dan investasi di kawasan."

Dilihat dalam penjelasan di atas, peran APEC bagi negara Asia Pasifik sangatlah besar dalam bidang ekonomi terutama untuk memastikan terjadinya stabilitas dalam meningkatkan kerja sama dan perdagangan antar negara. Pembentukan APEC akan memudahkan negara anggota dalam berkomunikasi dan berinteraksi mengenai kerja sama ekonomi yang berkelanjutan dan memiliki dampak positif bagi setiap anggota.

Pembentukan APEC bertujuan untuk membuat ekonomi kawasan Asia Pasifik berjalan dinamis. Dalam memenuhi kebutuhan dan meningkatkan perekonomian tiap Negara anggota. Kawasan Asia Pasifik juga dapat menjadi kawasan yang berdaya saing ekonomi tinggi, seperti Eropa dan Amerika Utara. Selain APEC, Australia dan China juga masuk dalam Regional Comprehensive Economic Partnership (RCEP). Organisasi ini merupakan organisasi yang terbentuk pada tahun 2011, sebagai bentuk perimbangan dari TPP. RCEP berfokus terhadap kerja sama ekonomi di kawasan Asia Tenggara.

\subsection{Kerja sama Australia dengan Negara di Asia Pasifik}

Kerja sama yang dilakukan oleh Australia saat ini banyak ditemukan dengan kerja sama Negara di Asia Tenggara, melalui kerja sama bilateral maupun multilateral kawasan di Asia Tenggara seperti yang dikenal sebagai Association of Southeast Asian Nation (ASEAN). seperti:

Kerja sama Australia dengan negara di Asia Pasifik dalam kerangka multilateral,

1. Indian Ocean Rim Association for Regional Cooperation (IOR-ARC)

IOR-ARC dibentuk pada tahun 1997, yang menghubungkan negara-negara yang berada di kawasan Samudera Hindia. Negara-negara yang masuk keanggotaan IOR-ARC adalah Indonesia, Malaysia, Singapura, Thailand, Australia, Bangladesh, India, Iran, Kenya, Madagaskar, Mauritius, Mozambik, Oman, Afrika Selatan, Saudi Arabia, Sri Lanka, Tanzania, Uni Emirat Arab, dan Yaman. Selain itu, yang menjadi rekan dialog IOR-ARC adalah China, Mesir, Inggris, Prancis, Jepang dan Qatar. Tujuan dibentuknya IOR-ARC adalah untuk memudahkan perdagangan dan investasi antar negara anggota.

2. Pacific Islands Forum (PIF)

Pacific Islands Forum yang awalnya bernama South Pacific Forum (SPF) dibentuk pada tanggal 7 Agustus 1971, adalah organisasi internasional di kawasan Asia Pasifik yang menjadi wadah kerja sama ekonomi dan sosial negara-negara 
Pasifik. 15 negara masuk dalam keanggotaan organisasi tersebut, termasuk Australia dan Selandia Baru.

3. Southeast Asia Treaty Organization (SEATO)

SEATO adalah organisasi internasional di bidang pertahanan yang dibentuk pada tangga 8 September 1954. Berawal dari Southeast Asia Collective Defence Treaty, SEATO menjadi sebuah organisasi yang mencoba meredam paham komunis di Asia Tenggara pada masa Perang Dingin. Negara yang masuk dalam keanggotaan SEATO adalah Amerika Serikat, Australia, Filipina, Inggris, Pakistan, Prancis, Selandia Baru, dan Thailand. SEATO sangat berbeda dengan NATO. Di dalam SEATO tidak ada unit dan struktur perintah militer dan hanya menjadi wadah dialog antar Negara anggota

4. Trans-Pacific Partnership (TPP)

Trans-Pacific Partnership adalah perjanjian perdagangan antara Australia, Peru, Vietnam, Singapura, Chili, Selandia Baru, Brunei Darussalam, Amerika Serikat, Kanada, Malaysia, Meksiko, dan Jepang. Negosiasi yang dilakukan oleh negara anggota di TPP membahas mengenai perdagangan dan investasi sudah sebanyak 19 round.

\subsection{Kerja Sama China dengan Negara Kawasan Asia Pasifik}

\subsubsection{ASEAN + 3}

Terbentuknya ASEAN + 3 disebabkan oleh krisis ekonomi pada tahun 1997 . Negara di kawasan Asia Tenggara semakin memandang pentingnya kerja sama ekonomi, terutama dengan kawasan Asia Timur. Melalui ACFTA, China berusaha untuk membuka pasar Asia Tenggara untuk produk pertanian dan manufakturnya. Pada tahun 2004, China dan ASEAN bersepakat untuk meliberalisasi pasar di bidang jasa dan investasi.

\subsubsection{Shanghai Cooperation Organization (SCO)}

SCO dibentuk pada tanggal 15 Juni 2001, dengan China sebagai pelopor. Selain China, SCO memiliki anggota Kazakhstan, Kyrgyztan, Rusia, Tajikistan, dan Uzbekistan. Negara pengamat di SCO yaitu India, Iran, Mongolia, dan Pakistan.

SCO adalah bentuk jalur sutera modern China yang menghubungkan negaranegara Asia Timur dan Asia Tengah untuk memudahkan kerja sama di bidang energi. SCO juga merupakan upaya China mengintegrasikan kawasan Asia Timur dan Asia Tengah. Noam Chomsky, salah satu pemerhati kebijakan luar negeri Amerika Serikat menjelaskan pentingnya SCO bagi perekonomian China dengan mengatakan:

"Salah satu bagian program ini berupa jalan raya yang melintasi beberapa gunung tertinggi menuju Gwadar, pelabuhan baru buatan Tiongkok di Pakistan. Pelabuhan ini akan mengamankan pengiriman minyak dari kemungkinan gangguan Amerika Serikat. Tiongkok dan Pakistan berharap program ini dapat memacu pengembangan industri Pakistan. Ini belum diupayakan Amerika Serikat, meskipun telah memberi bantuan militer cukup besar. Program ini juga memberi insentif bagi Pakistan untuk menekan terorisme domestik, masalah serius Tiongkok di barat Provinsi Xinjiang. Gwadar menjadi bagian "kalung mutiara" Tiongkok, basis yang sedang dibangun di 


\begin{abstract}
Samudera Hindia. Selain bertujuan komersial, Gwadar juga berpotensi sebagai kekuatan militer. Ini seiring harapan Tiongkok kelak mendapat proyek pengembangan listrik hingga Teluk Persia pada era modern. (Chomsky, 2016)."
\end{abstract}

Pesatnya perekonomian China mempengaruhi keinginannya untuk memperluas pengaruh melalui "rekan baru", seperti Asia Tengah. Negara di Asia Tengah merupakan negara-negara yang tidak terlalu menarik perhatian Amerika Serikat, sehingga China mengambil kesempatan ini untuk memperluas jaringan ekonominya. Selain ekonomi, jalan sutera modern China juga bergerak dalam bidang politik dan keamanan.

\title{
4.5 Pengaruh Kerja sama Ekonomi Antara Australia dan China Dengan Negara di Pasifik terhadap Politik di Asia Pasifik
}

Kawasan Asia Pasifik dilihat secara umum merupakan salah satu kawasan yang stabil karena keseimbangan antara dua kekuatan, yaitu Australia dan China. Kawasan Asia Tenggara merupakan kawasan persaingan pengaruh antara Australia dan China. Beberapa negara di Asia Tenggara bahkan diidentikkan sebagai "mitra" Australia maupun China.

Kerja sama ekonomi yang telah dilakukan oleh Australia dan China dengan negara di kawasan Asia Pasifik telah mempengaruhi politik di kawasan Asia Pasifik. Kerja sama tersebut adalah salah satu jalan bagi kedua negara ini untuk menancapkan pengaruhnya yang semakin dalam. Kerja sama ekonomi antara Australia dan China dengan negara-negara Asia Pasifik semakin mempererat hubungan mereka dalam hal politik. Hingga terbentuk blok yang terlihat samar namun dapat dikenali dengan baik karena memiliki perbedaan ideologi.

Terkait dengan Asia Tenggara, kedua negara ini memiliki pengaruhnya masingmasing terhadap kawasan tersebut. Pengaruh tersebut hadir karena sangat intensifnya berbagai kerja sama yang dilakukan. Asia Tenggara merupakan kawasan penting bagi Asia Pasifik dan dapat menjadi contoh bagaimana hubungan kerja sama ekonomi mempengaruhi hubungan politik antara Australia maupun China di Kawasan Asia Tenggara.

Myanmar adalah salah satu negara di Asia Tenggara yang memiliki hubungan dekat dengan China. Jika ditelusuri melalui sejarah dan dibandingkan dengan dua kekuatan ideologi pada masa Perang Dingin. Myanmar yang diperintah oleh kekuatan militer ditentang oleh Amerika Serikat dengan mengatasnamakan demokrasi. Berbeda dengan Amerika Serikat dan sekutunya Australia, China tidak memiliki masalah dengan demokrasi maupun isu hak asasi manusia di Myanmar. Hal ini semakin mempererat hubungan antara Myanmar dan China. Selain Myanmar, negara di Asia Tenggara yang condong ke China adalah Laos dan Vietnam, kedua negara ini memiliki sistem yang sama dengan China yaitu sistem ekonomi yang terbuka, namun sistem politiknya tertutup (Weatherbee, 2009).

Pada tahun 1975, China menjadi negara kedua yang melakukan investasi di Laos. Hubungan antara China dan Laos tergolong dekat karena dipengaruhi oleh ideologi yang sama. Laos adalah mitra China dalam pembangunan infrastruktur yang menghubungkan barat daya China dengan Asia Tenggara. Berbeda dengan Myanmar, Filipina adalah salah satu negara yang memiliki hubungan yang erat dengan Australia. Dalam programnya melawan terorisme, Filipina bekerja sama dengan Amerika Serikat dan Australia. Australia berjanji kepada Filipina akan memberikan tiga puluh perahu cepat untuk patroli sungai dan muara laut. Selain Filipina, Singapura dan Malaysia juga memiliki hubungan yang dekat dengan Australia (Weatherbee, 2009).

Keinginan Australia adalah menjadikan Asia Pasifik sebagai sebuah komunitas utuh, yang dapat menggabungkan kepentingan antara Amerika Serikat dan China. Australia berharap bahwa penggabungan dua kepentingan antara Amerika Serikat dan China ini akan 
membawa situasi dan kondisi yang lebih baik tidak hanya untuk Australia, tetapi juga untuk kawasan Asia Pasifik (Connors, 2004).

\section{Kesimpulan}

Berdasarkan penjelasan di atas, persaingan kepemimpinan antara Australia dan China dalam institusi regional di kawasan Pasifik masih akan tetap terjadi meskipun kedua negara terlibat dalam hubungan interdependensi yang sangat kuat. Bagi Australia, perannya dalam organisasi regional merupakan salah satu cara untuk menghadang kemajuan China yang pesat dalam hal ekonomi dan keamanan di kawasan Asia Pasifik. Sementara itu, bagi China, forum multilateral tersebut bermanfaat untuk memperkuat posisinya sebagai kekuatan regional baru di Kawasan Asia Pasifik.

Pada akhirnya, hanya kepentingan nasional saja yang memotivasi kedua negara untuk mengambil langkah dalam institusi regional yang mereka ikuti, sesuai dengan pandangan Realisme. Interdependensi ekonomi antara Australia dan China yang pada awalnya merupakan hal yang baik serta mampu membawa integrasi regional pada akhirnya akan menjadi rivalitas apabila hubungan kedua negara didasari oleh ambisi nasional atau keinginan untuk meraih kepentingan tertentu serta didorong oleh agenda ekonomi dan militer yang ekspansionis. Inilah yang terlihat dalam hubungan antara Australia dan China dalam menjalankan perannya di institusi regional dengan didasarkan pada pemahaman budaya dan politik serta ideologi yang berbeda.

Politik di kawasan Asia Pasifik dipengaruhi oleh dua kekuatan ideologi besar yang dibawa oleh dua negara. Kemajuan Australia dan China dalam bidang ekonomi adalah keberhasilan mereka dalam memanfaatkan sumber daya yang dipadukan dengan strategi. Dua kekuatan besar ini berusaha menanamkan pengaruhnya di bidang ekonomi terutama terhadap negara-negara yang berada di Asia Pasifik. Salah satu langkah melalui kerja sama yang dilakukan baik di bidang politik, pertahanan, maupun ekonomi dengan negara yang berada di kawasan Asia Tenggara.

Kawasan Asia Pasifik merupakan kawasan yang unik, meskipun Australia adalah mitra dari Amerika Serikat di Asia Pasifik, Australia tidak melakukan tindakan agresif seperti Amerika Serikat dalam menanggapi manuver politik China terkait konflik di Laut China Selatan. 


\section{DAFTAR PUSTAKA}

\section{Artikel}

Gregory C, Chow. (2005). Globalization and China's Economic and Financial Development.

\section{Buku}

Chomsky, Noam. (2016). Who Rules the World?. USA: Metropolitan Books Henry Holt and Company.

Connors, Micahel K, et al. (2004). The New Global Poltics of the Asia Pacific. USA: Routledge Curzon.

Haneman, Thilo \& Huotari, Mikko. (2016). A New Record Year for Chinese Outbound Investment in Europe. Berlin: Mercator Institute for China Studies.

McMichael, Philip. (1984). Settlers and The Agrarian Question Foundations of Capitalism in Colonial Australia. UK: Cambridge University Press.

Norberg, Johan. (2011). Membela Kapitalisme Global. Jakarta: Freedom Institute.

Perwita, A A B dan Yanyan M Y. (2005). Pengantar Ilmu hubungan Internasional. Bandung: PT. Remaja Rosdakarya, Bandung.

Sugiyono. (2011). Motode Penelitian Kualitatif R\&B. Bandung: Alfabeta.

Weatherbee, Donald E. (2009). International Relations in Southeast Asia: The Struggle for Autonomy. USA: Rowman \& Littlefield Publishers, Inc.

\section{Jurnal}

Jati, Wasisto Raharjo. (2013). Global City sebagai Paradigma Pembangunan Ekonomi Kota di Era Globalisasi: Tinjauan Analisis Teori. Multiversa. Volume 03.

OECD. (2017). Development in Individual OECD and Selected Non-Member Economies: China. OECD Economic Outlook. Vol 2017.

Keohane, R. O dan Joseph, Nye. (1989). Power and Interdependence 2nd edition. New York: Harpers.

Morgenthau, Hans J. (1993). Politics Among Nations: The Struggle for Power and Peace. MacGraw-Hill.

Prasetyo, Sigit. (2011). APEC dan Proses Integrasi Ekonomi Regional di Kawasan Asia Pasifik. Jurnal Kajian Wilayah Vol. 2 No. 2

Viotti, Paul R. dan Mark, Kauppi. (2010). International Relation Theory. New York: Pearson Education Inc.

Wilson, Jeffrey D. (2015). Mega-Regional Trade Deals in the Asia-Pacific: Choosing Between the TPP and RCEP?. Journal of Contemporary Asia. Vol 45.

\section{Laporan}

Australian Industry Report 2016. 